\title{
AKTIVITAS SENYAWA ANTIBAKTERI EKSTRAK PAREPAT (Sonneratia alba) TERHADAP PERTUMBUHAN Ralstonia solanacearum DAN Streptococcus sobrinus
}

\author{
Saat Egra $^{1}$, Mardhiana ${ }^{1}$, Ningrum Indah Rahayu ${ }^{1}$, Nurjannah $^{1}$, Sudirman Sirait ${ }^{1}$, Dwi Santoso ${ }^{1}$, \\ Ankardiansyah Pandu Pradana ${ }^{2}$, Harlinda Kuspradini ${ }^{3} \&$ Tohru Mitsunaga $^{4}$ \\ ${ }^{1}$ Jurusan Agroteknologi, Fakultas Pertanian, Universitas Borneo Tarakan \\ ${ }^{2}$ Jurusan Proteksi Tanaman, Fakultas Pertanian, Universitas Jember \\ ${ }^{3}$ Fakultas Kehutanan, Universitas Mulawarman \\ ${ }^{4}$ The United Graduate School of Agricultural Science, Gifu University \\ Email : saat.egra.shaumi@gmail.com
}

Diterima: 10 Agustus 2020

Disetujui: 26 September 2020

\begin{abstract}
Parepat/pidada putih (Sonneratia alba) is a type of mangrove plant that is used by the traditional tribe for natural medicine. This study uses leaves and stem bark extracted with ethanol. Antibacterial assay uses Ralstonia Solanaceaerum and Streptococcus sobrinus by diffusion agar method. The concentrations used were 5000ppm, $10000 \mathrm{ppm}, 20000 \mathrm{ppm}$ with positive control (Chloramphenicol), and negative control (Ethanol 40\%). The results of this study obtain the moisture factor of S. alba leaves has a humidity of 0.31 and stem bark of 0.49 . The yield showed that the amount of $S$. alba leaf extract was $23.86 \%$ and the bark was $7.31 \%$. S. alba leaf extract was able to inhibit the bacteria $R$. solanacearum at concentrations of $5000 \mathrm{ppm}, 10000 \mathrm{ppm}$ and $20000 \mathrm{ppm}$ with inhibitory values of $27.46 \%$, $34.34 \%$ and $37.78 \%$, respectively. While bark extract can inhibit $R$. solanacearum at concentrations of $5000 \mathrm{ppm}$, $10000 \mathrm{ppm}$ and $20000 \mathrm{ppm}$ with inhibitory values of $35.38 \%, 38.47 \%$ and $41.92 \%$, respectively. S. alba leaf extract is able to inhibit $S$. sobrinus bacteria only at concentrations of $10000 \mathrm{ppm}$ and $20000 \mathrm{ppm}$ with inhibitory values of $28.07 \%$ and $48.51 \%$. Whereas S. alba bark extract was able to inhibit S. sobrinus at a concentration of $5000 \mathrm{ppm}, 10000$ ppm and $20000 \mathrm{ppm}$ with inhibitory values of $16.18 \%, 49.02 \%$ and $61.27 \%$.
\end{abstract}

Keywords: Antibacterial, Leave, Stem bark, Mangrove, S. alba

\begin{abstract}
ABSTRAK
Parepat/pidada putih (Sonneratia alba) merupakan salah satu jenis tumbuhan mangrove yang dimanfaatkan oleh masyarakat sebagai obat tradisional. Penelitian ini menggunakan daun dan kulit batang yang diekstraksi dengan etanol. Pengujian antibakteri menggunakan Ralstonia Solanaceaerum dan Streptococcus sobrinus dengan metode difusi agar sumuran. Kosentrasi yang digunakan yaitu 5000 ppm, 10000 ppm, 20000 ppm dengan kontrol positif (Chloramphenicol), dan kontrol negatif (Etanol 40\%). Hasil penelitian ini menunjukkan faktor kelembaban daun S. alba memiliki kelembaban yaitu 0,31 dan kulit batang yaitu 0,49 . Rendemen menunjukkan bahwa jumlah ekstrak daun $S$. alba yaitu 23,86\% dan kulit batang 7,31\%. Ekstrak daun $S$. alba mampu menghambat bakteri $R$. solanacearum pada konsentrasi 5000ppm, 10000ppm dan 20000ppm dengan nilai persentase hambat yaitu masing-masing 27,46\%, 34,34\% dan $37,78 \%$. Sedangkan ekstrak kulit batang mampu menghambat $R$. solanacearum pada konsentrasi $5000 \mathrm{ppm}, 10000$ ppm dan 20000 ppm dengan nilai persentase hambat secara berturut 35,38\%, 38,47\% dan 41,92\%. Ekstrak daun S. alba mampu menghambat bakteri S. sobrinus hanya pada konsentrasi 10000 ppm dan $20000 \mathrm{ppm}$ dengan nilai persentase hambat yaitu $28,07 \%$ dan $48,51 \%$. Sedangkan ekstrak kulit batang S. alba mampu menghambat S. sobrinus pada konsentrasi 5000 ppm, 10000 ppm dan 20000 ppm dengan nilai persentase hambat yaitu 16,18\%, 49,02\% dan 61,27\%.
\end{abstract}

Kata kunci: Antibakteri, Daun, Kulit bantang, Mangrove, S. alba.

\section{PENDAHULUAN}

Tumbuhan mangrove terluas di dunia ternyata ada di Indonesia dengan 4,5 juta hektar, diikuti dengan negara Brazil (1,3 juta hektar), Nigeria (1,1 juta hektar) dan Australia (0,97 juta hektar), hal ini disebabkan wilayah tumbuhnya berada di garis katulistiwa. Ada berbagai jenis tumbuhan mangrove di Indonesia seperti Sonneratia alba, Ceriops, Bruguiera, Rhizhopora, Avicennia marina, Avicennia alba, Sonneratia caesolaris dan Nypa fructicans (Noor dkk 2006). Sonneratia alba memiliki nama lokal perepat atau pidada putih merupakan tumbuhan mangrove yang memiliki banyak manfaat, dalam kehidupan sehari-hari secara tradisional tumbuhan mangrove digunakan 
masyarakat sebagai obat TBC, sakit gigi, sakit kepala, keseleo, asma, diare, disentri, demam, pendarahan (Bandarnayake 2002).

Tumbuhan mangrove menghasilkan metabolit sekunder yang mengandung senyawa bioaktif seperti flavonoid, alkoloid, fenol, terpenoid dan zat-zat kimia sekunder lainnya (Mulyani dkk. 2013). Metabolit sekunder disintesis oleh tumbuhan sebagai sistem pertahanan terhadap infeksi oleh mikroorganisme, sehingga senyawa ini efektif sebagai antimikroba terhadap sejumlah mikroorganisme (Trianto dkk. 2004). Daun mangrove diketahui mengandung senyawa aktif seperti steroid, saponin, flavonoid dan tanin yang memiliki kemampuan dalam menghambat pertumbuhan beberapa jenis bakteri (Purnobasuki 2004). Karena kemampuannya sebagai antibakteri ini tumbuhan mangrove banyak dimanfaatkan oleh masyarakat untuk kesehatan gigi dan mulut manusia. Salah satu bakteri penyebab karies gigi ialah Streptococcus sobrinus. Bakteri ini bersifat patogen dan banyak ditemukan di rongga mulut juga merupakan bakteri penyebab awal proses karies gigi. Menurut Sjahid (2008), senyawa alkaloid yang terdapat pada ekstrak mangrove mampu menghambat pembentukan dinding sel bakteri Gram positif seperti $S$. sobrinus. Terhambatnya pembentukan dinding sel bakteri mengakibatkan bakteri tersebut tidak dapat berkembangbiak dan mati. Kemampuannya sebagai antimikroba membuatnya dimanfaatkan sebagai pestisida nabati.

Tumbuhan mangrove selain dimanfaatkan sebagai obat tradisional juga dimanfaatkan sebagai bahan pertanian tradisional seperti insektisida dan pestisida nabati yang dapat mengendalikan penyakit tanaman seperti layu fusarium. Layu fusarium merupakan penyakit tanaman yang disebabkan oleh bakteri Ralstonia solanacearum. Ekstrak daun majapahit mampu menghambat pertumbuhan $R$. solanacearum secara in vitro, karena mengandung senyawa fenol, flavonoid, tanin, saponin, dan alkaloid yang bersifat antibakteri (Dewi 2014).

Kegunaan dan khasiat yang diperoleh dari berbagai jenis tumbuhan mangrove sangat banyak, namun sejauh ini masih sedikit penelitian yang mengungkapkan aktifitas antibakteri dari ekstrak tumbuhan mangrove, sehingga diperlukan penelitian untuk mengetahui potensi dari ekstrak tumbuhan mangrove $S$. alba dalam menghambat pertumbuhan bakteri $R$. solanacaerum dan $S$. sobrinus.

\section{METODE}

\section{Alat, Bahan dan Tempat Penelitian}

Laboratorium Natural Product Chemisry dan Hama Penyakit Tanaman menjadi tempat penelitian ini. Daun dan kulit batang S. alba diambil dari Kawasan Konservasi Mangrove dan Bekantan (KKMB) Kota Tarakan. Dalam penelitian ini menggunakan aquades, etanol, mikroba S. sobrinus dan $R$. solanacearum, agar, nutrient broth, chloramphenicol. Peralatan yang digunakan adalah spektrofotometer model Shimadzu UV Vis 1200 (Shimadzu co, Jepang), evaporator, shaker, oven, autoclave model All Americans.

\section{Persiapan Sampel, Faktor Kelembaban (MF) dan Rendemen}

Persiapan sampel dengan membersihkan dan mengeringkan daun dan kulit batang sampel selama 3-6 hari pada suhu ruang. Setelah kering, kemudian dihomogenkan ukurannya menjadi kecil lalu direndam dengan etanol $96 \%$ dan dievaporator. Faktor kelembaban, sampel dipotong hingga menjadi beberapa bagian agar mudah dalam proses pengeringan di oven pada suhu $100 \mathrm{OC}$ selama $1 \mathrm{x}$ 24 jam. Untuk menghitung nilai faktor kelembaban yaitu dengan berat kering tanur dibagi dengan berat awal. Kemudian persiapan dan faktor kelembaban akan didapatkan nilai rendemen dengan membagi berat ekstrak dengan berat sampel segar dikali dengan faktor kelembaban dikali 100\% (Egra, 2019).

\section{Pengujian Aktivitas Antimikroba}

Media pertumbuhan bakteri yang utama adalah menggunakan nutrient broth (Difco), glukosa, kemudian dilarutkan hingga homogen dalam aquades dan disterilisasi dengan autoclave pada suhu $121^{\circ} \mathrm{C}$ selama 20 menit. Metode yang digunakan adalah difusi agar sumuran dan suspensi bakteri setera dengan $10^{6} \mathrm{cells} / \mathrm{ml}$. Selanjutnya ekstrak diuji dalam beberapa konsentrasi (20000ppm, 10000ppm dan 5000ppm). Chloramphenicol digunakan sebagai control positif dan kontrol negatifnya adalah etanol $40 \%$. Penghambatan antimikroba ditandai dengan adanya zona hambat disekitar sumuran yang mengandung ekstrak, dengan angka lebih besar dari $8 \mathrm{~mm}$ (Yanti, 2018).

\section{HASIL DAN PEMBAHASAN}

\section{Faktor Kelembaban (Moisture Factor)}

Penghitungan faktor kelembaban bertujuan untuk mengetahui kondisi kelembaban atau kadar air dari suatu sampel. Penghitungan ini dilakukan setelah memperoleh berat tanur dari sampel yang digunakan. Sampel segar daun dan kulit batang $S$. alba dengan berat masing-masing yaitu 1 gram dan diulang sebanyak 3 kali. Sehingga diperoleh ratarata berat kering tanur daun $S$. alba yaitu 0,313 gram dan rata-rata berat kering tanur kulit batang $S$. alba yaitu 0,49 gram. Berdasarkan hasil penghitungan faktor kelembaban, daun $S$. alba memiliki 
kelembaban yaitu 0,31 dan kulit batang $S$. alba memiliki kelembaban yaitu 0,49 .

Kelembaban relatif dan kadar air pada sampel menggambarkan aktivitas air didalamnya. Selain kelembaban dan suhu, pengeringan juga merupakan faktor yang dapat mempengaruhi kualitas sampel sehingga dapat digunakan sebagai ekstrak. Faktor kelembaban didapatkan dari pengeringan yang menggunakan suhu tinggi. Semakin tinggi suhu pengeringan maka semakin cepat penurunan kadar air pada sampel. Tingginya suhu udara pada proses pengeringan mempunyai pengaruh yang sangat besar dalam kecepatan perpindahan uap air (Rizki 2018).

Faktor kelembaban daun dan kulit batang $S$. alba menunjukkan nilai yang berbeda. Daun $S$. alba memiliki faktor kelembaban yaitu 0,31 dan kulit batang $S$. alba memiliki faktor kelembaban yaitu 0,49. Pada kelembaban sampel daun dan kulit batang $S$. alba dapat dijadikan sebagai ekstrak dengan

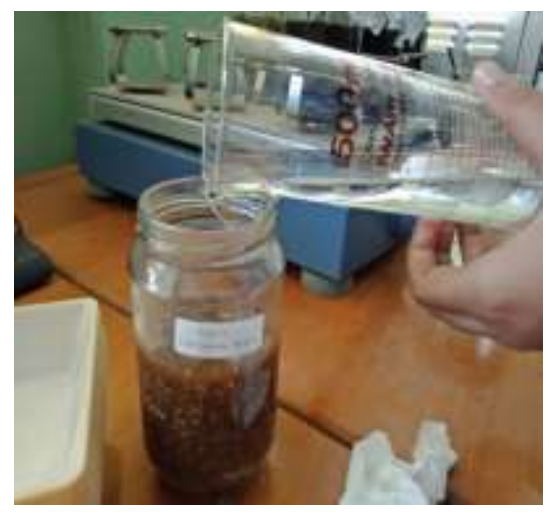

a. Proses ekstraksi

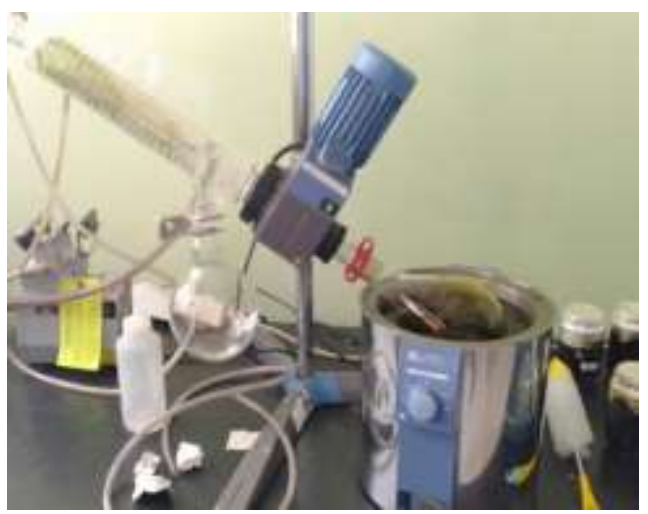

c. Proses evaporasi kualitas yang baik karena sampel sulit untuk ditumbuhi oleh bakteri ataupun jamur. Beberapa bakteri tidak dapat tumbuh pada nilai aktivitas air dibawah 0,87 dan jamur dapat tumbuh pada nilai aktivitas air 0,75 - 0,65 (Tapia dkk. 2007).

\section{Persentase Rendemen}

Penghitungan persentase rendemen didapatkan dari bobot ekstrak sampel yang diperoleh dari proses ekstraksi. Ekstraksi daun dan kulit batang $S$. alba dilakukan menggunakan metode maserasi. Hasil rendemen menunjukkan bahwa jumlah ekstrak daun $S$. Alba adalah $(23,86 \%)$ dan kulit batang $S$. alba $(7,31 \%)$. Semakin tinggi nilai rendemen menandakan bahwa jumlah ekstrak yang dihasilkan semakin banyak. Menurut Wijaya dkk. (2018) metode ekstraksi yang digunakan merupakan salah satu faktor yang akan mempengaruhi rendemen suatu ekstrak.

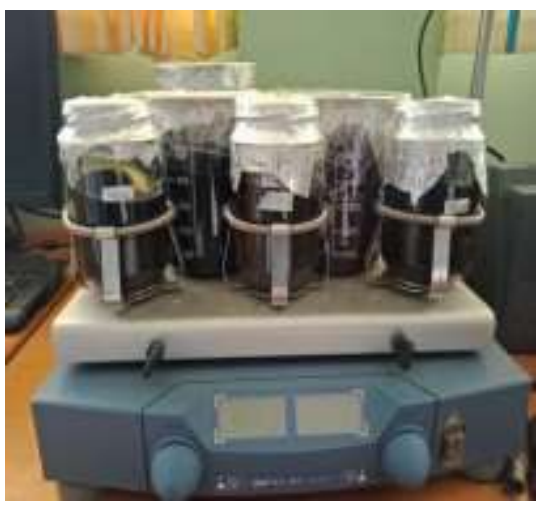

b. Proses pengadukan

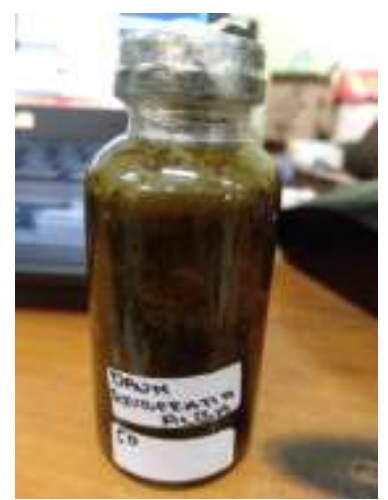

d. Esktrak

Gambar 1. Proses Pembuatan ekstrak S. alba

Ekstraksi dilakukan dengan menggunakan pelarut tunggal yaitu etanol. Pelarut yang digunakan harus memiliki sifat kepolaran yang sama dengan senyawa yang akan ditarik (Sudarmadji 2009). Menurut Siregar dkk. (2015) pelarut etanol memiliki polaritas yang tinggi sehingga dapat mengekstrak senyawa yang bersifat polar, diantaranya senyawa fenolik, steroid, terpenoid, alkaloid dan glikosida.
Etanol merupakan pelarut yang lebih baik dibandingkan dengan air dan heksana jika akan mengekstrak komponen antimikroba (Ahmad dkk. 2002).

Berdasarkan hasil penghitungan persentase rendemen tertinggi diperoleh dari ekstrak daun $S$. alba yaitu 23,86\% sedangkan persentase rendemen kulit batang $S$. alba yaitu $7,31 \%$. Bobot simplisia 
daun S. alba lebih besar yaitu 126,94 gram sedangkan bobot simplisia kulit batang $S$. alba yaitu 48,91 gram. Semakin tinggi nilai rendemen yang dihasilkan maka nilai ekstrak yang dihasilkan semakin banyak. Hasil rendemen dipengaruhi oleh beberapa faktor seperti jumlah simplisia, lama perendaman dan pengeringan. Menurut Irsyad (2013) hasil rendemen dapat dijadikan acuan untuk mengetahui jumlah simplisia yang dibutuhkan untuk pembuatan sejumlah tertentu ekstrak kental. Menurut Kristian dkk. (2016) semakin lama ekstraksi dengan waktu yang optimal, maka semakin tinggi rendemen yang dihasilkan. Semakin tinggi suhu pengeringan dan lama perlakuan pengeringannya, maka nilai rendemen yang dihasilkan semakin tinggi dikarenakan kadar air pada ekstrak menyusut (Rizki 2018).

\section{Persentase Penghambatan}

Diameter aktifitas antimikroba dilakukan dengan cara mengukur diameter daerah hambat menggunakan mistar di sekitar sumuran berbentuk zona bening pada lubang sampel uji. Persentase penghambatan ditentukan berdasarkan rata-rata daya hambat relatif setiap kosentrasi terhadap kontrol positif setelah diinkubasi selama 18-24jam pada

Tabel 1. Persentase penghambatan suhu $37^{\circ} \mathrm{C}$. Kontrol positif yang digunakan adalah Chloramphenicol sebesar 200ppm dan kontrol negatif adalah etanol 40\%. Kontrol positif (Chloramphenicol 200 ppm) digunakan sebagai pembanding karena merupakan antibiotik spektrum luas yang dapat menghambat bakteri Gram negatif dan positif, sehingga kontrol positif menghasilkan zona bening paling besar (Chan et al. 2008). Menurut Olson et al. (2004) mekanisme dari Chloramphenicol yaitu menghambat sintesis protein, mencegah ujung aminoasil t-RNA bergabung dengan peptidil transferase.

Kontrol negatif berupa etanol 40\% yang digunakan merupakan pelarut pada proses ekstraksi. Hal ini dilakukan untuk mengetahui bahwa etanol $40 \%$ tidak berperan dalam membentuk zona hambat dan untuk mengetahui ada tidaknya pengaruh pelarut terhadap pertumbuhan $R$. solanacearum dan $S$. sobrinus. Sehingga dapat diasumsikan bahwa yang mempunyai aktivitas antibakteri adalah sampel uji (ekstrak S. alba) bukan pelarut. Hasil uji aktivitas antibakteri ekstrak daun dan kulit batang S. alba terhadap R. solanacearum diamati setelah inkubasi 18 jam. Hasil penghitungan persentase penghambatan dapat dilihat pada Tabel 1.

\begin{tabular}{ccccccc}
\hline & \multicolumn{6}{c}{ Persentase Penghambatan (\%) } \\
\cline { 2 - 7 } Nama Tumbuhan & \multicolumn{3}{c}{ Bakteri R. solanacearum } & \multicolumn{3}{c}{ Bakteri S. sobrinus } \\
\cline { 2 - 7 } & 5000 & 10000 & 20000 & 5000 & 10000 & 20000 \\
& $\mathrm{ppm}$ & $\mathrm{ppm}$ & $\mathrm{ppm}$ & $\mathrm{ppm}$ & $\mathrm{ppm}$ & $\mathrm{ppm}$ \\
\hline Daun S. alba & 25 & 31 & 34 & 0 & 28 & 49 \\
Kulit Batang S. alba & 39 & 43 & 47 & 16 & 49 & 61 \\
Chloramphenicol & & 100 & & & 100 & \\
\hline
\end{tabular}

Persentase penghambatan pada $R$. solanacearum menunjukkan bahwa ekstrak daun dan kulit batang $S$. alba memiliki aktivitas antibakteri dengan konsentrasi 20000 ppm memiliki nilai tertinggi dalam menghambat yaitu $34 \%$ dan $47 \%$. Selain itu, ekstrak daun dan kulit batang $S$. alba juga memiliki aktivitas antibakteri yang mampu menghambat pertumbuhan bakteri $S$. sobrinus. Kontrol positif (Chloramphenicol) pada S. sobrinus juga memiliki daya hambat $100 \%$ dan kontrol negatif (Etanol) tidak memiliki daya hambat. Ekstrak daun dan kulit batang $S$. alba dengan konsentrasi 20000ppm memiliki nilai tertinggi dalam menghambat S. sobrinus yaitu $49 \%$ dan $61 \%$. Diagram diameter daerah hambat pada ekstrak daun dan kulit batang $S$. alba terhadap $R$. solanacearum dapat dilihat pada Gambar 1 dan diagram diameter daerah hambat pada ekstrak daun dan kulit batang $S$. alba terhadap S. sobrinus dapat dilihat pada Gambar 2. 


\section{Persentase Penghambatan terhadap $R$. solanacearum}

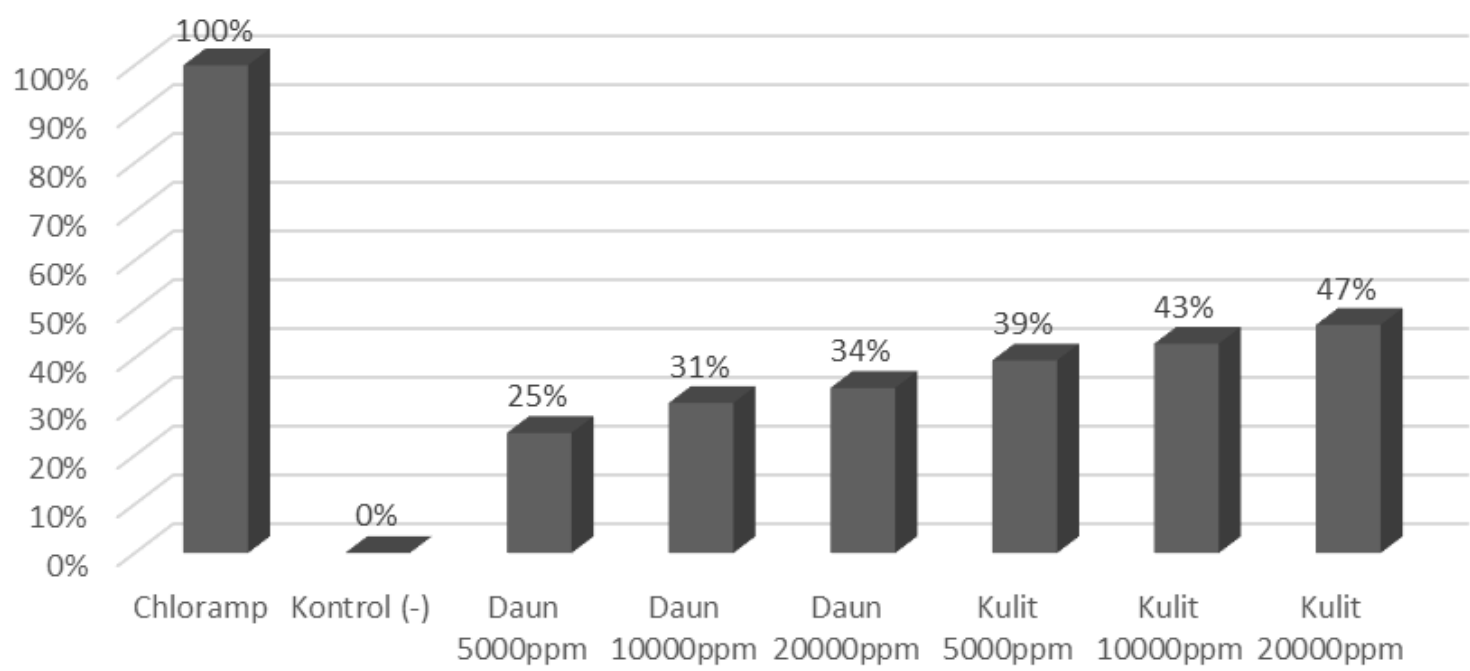

Gambar 2. Diagram diameter daerah hambat pada ekstrak daun dan kulit batang $S$. alba terhadap bakteri $R$. solanacearum.

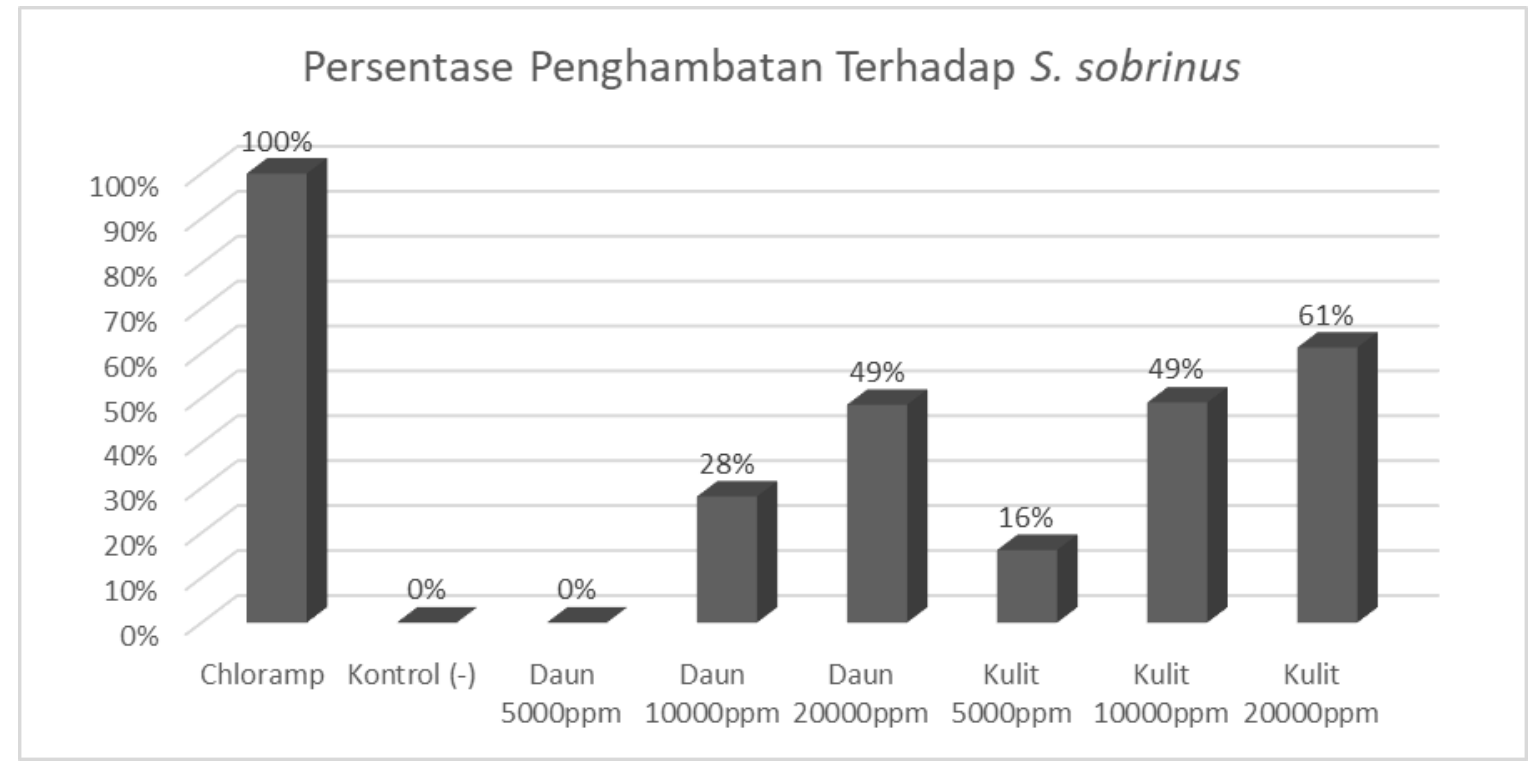

Gambar 3. Diagram diameter daerah hambat pada ekstrak daun dan kulit batang S. alba terhadap bakteri $S$. sobrinus.

Berdasarkan hasil pengujian antibakteri daun dan kulit batang $S$. alba terhadap bakteri $R$. solanacearum dan $S$. sobrinus memiliki hasil yang cukup signifikan, hal ini diduga peran metabolit sekunder pada sampel mempengaruhi daya hambat dari suatu ekstrak sehingga memberikan pengaruh terhadap pertumbuhan bakteri uji. Kandungan senyawa metabolit sekunder yang terdapat pada ekstrak $S$. alba adalah alkoloid, fenol, tanin, saponin dan flavonoid (Rizkinita dkk. 2016). Senyawa alkaloid memiliki kemampuan sebagai antibakteri dengan menganggu komponen penyusun peptidoglikan pada bakteri, sehingga lapisan dinding sel tidak terbentuk utuh kemudian menyebabkan kematian sel (Husna dkk. 2015). Mekanisme kerja alkaloid yaitu melalui penghambatan sintesis dinding sel yang akan menyebabkan lisis pada sel sehingga sel akan mati (Lamothe 2009).

Senyawa fenol pada konsentrasi tinggi bertindak sebagai toksin bagi plasma untuk merusak sistem dinding sel dan untuk menggumpalkan protein dalam sel, sedangkan pada konsentrasi rendah dapat menghambat multiplikasi enzim in vitro (Ogata dkk. 2000). Senyawa tanin merupakan senyawa organik yang aktif menghambat pertumbuhan mikroba dengan mekanisme merusak dinding sel mikroba dan membentuk ikatan dengan protein fungsional sel mikroba (Sudira dkk. 2011). Mekanisme kerja flavonoid sebagai antibakteri adalah membentuk senyawa kompleks dengan protein ekstraseluler dan terlarut sehingga dapat merusak membran sel bakteri dan diikuti dengan 
keluarnya senyawa intraseluler (Nuria dkk. 2009). Menurut Kusumadewi (2015) saponin bekerja sebagai antimikroba dengan menganggu stabilitas membran sel bakteri sehingga menyebabkan sel

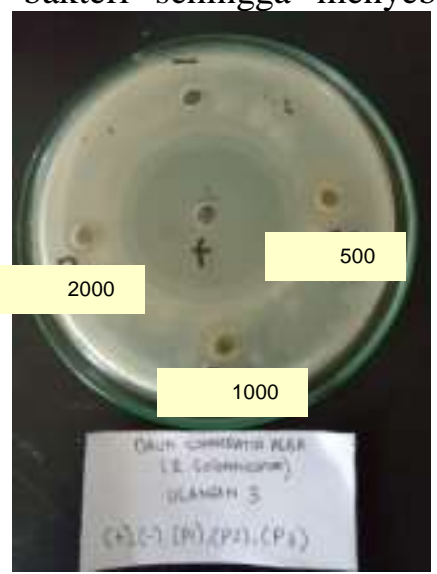

(a)

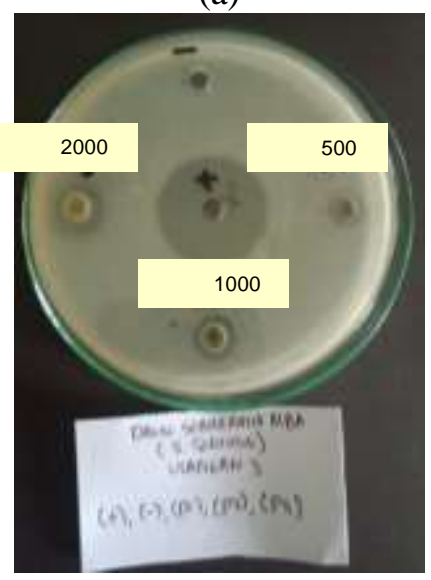

(c) bakterilisis. Hal ini menyebabkan sitoplasma bocor sehingga senyawa intraseluler keluar dari sel yang mengakibatkan kematian sel.

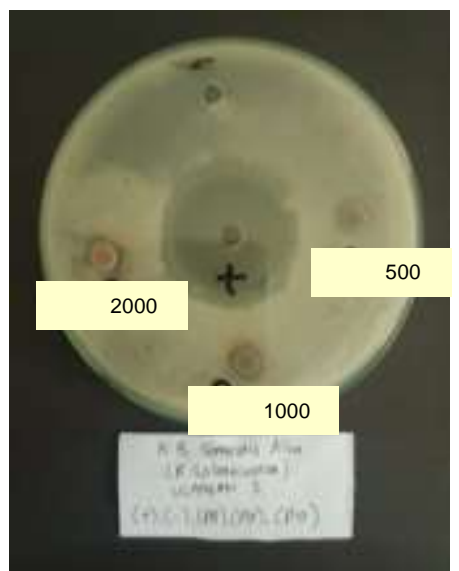

(b)

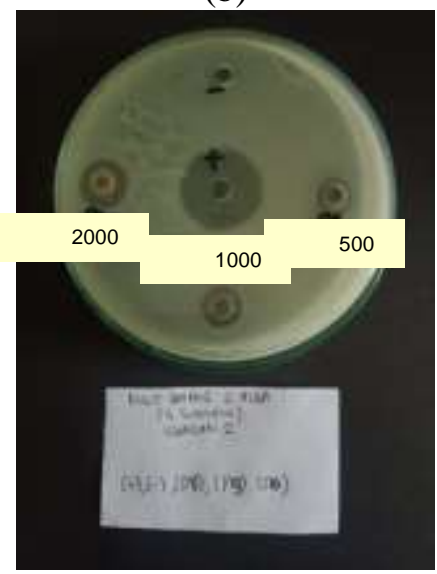

(d)

Gambar 4. Pengujian aktivitas antimikroba pada ekstrak (a) daun dan (b) kulit batang S. alba terhadap $R$. solanacearum, sedangkan ekstrak (c) daun dan (d) kulit batang S. alba terhadap S. Sobrinus dengan kosentrasi masing-masing 5000ppm, 10000ppm dan 20000ppm.

Diagram diameter daerah hambat pada ekstrak daun dan kulit batang $S$. Alba terhadap bakteri $S$. Sobrinus. Selain beberapa metabolit sekunder, jenis Gram bakteri juga mempengaruhi terbentuknya zona hambat. Pada gambar 1 dan 2 yaitu uji aktivitas antibakteri ekstrak daun dan kulit batang $S$. alba terhadap $R$. solanacearum menunjukkan hasil yang cukup baik. Menurut Pelczar (1986) struktur dinding sel bakteri Gram negatif lebih kompleks dibandingkan dengan struktur dinding sel Gram positif. Bakteri Gram negatif memiliki beberapa lapisan yaitu lapisan luar, lapisan tengah dan lapisan dalam. Sehingga, bakteri $R$. solanacearum ini memiliki struktur dinding sel yang relatif kompleks dan menyebabkan senyawa antibakteri lebih sulit masuk ke dalam sel dan menemukan sasaran untuk bekerja (Siswandono 2000). Disisi lain, kemampuan antibakteri terhadap S. sobrinus memiliki hasil yang lebih baik dan menghasilkan zona bening yang besar. Hal ini terjadi karena bakteri S. sobrinus merupakan golongan bakteri Gram positif yang mudah untuk dihambat. Bakteri Gram positif hanya memiliki satu lapisan dan lebih sensitif terhadap komponen antibakteri sehingga memudahkan senyawa antibakteri untuk masuk kedalam sel dan menemukan sasaran untuk bekerja (Putri dkk. 2016).

\section{KESIMPULAN}

Berdasarkan hasil uji jarak berganda taraf $1 \%$ (Tabel 9 dan Tabel 14), ekstrak kulit batang S. alba dengan konsentrasi 10000 ppm merupakan konsentrasi yang efektif dalam menghambat aktivitas bakteri $R$. solanacearum dan $S$. sobrinus. Ekstrak kulit batang S. alba menunjukkan aktivitas antibakteri yang tinggi dan berspektrum luas, sehingga berpotensi sebagai sumber antibakteri alami . 


\section{UCAPAN TERIMA KASIH}

Penulis mengucapkan terima kasih kepada Lembaga Penelitian dan Pengabdian kepada Masyarakat (LPPM), Universitas Borneo Tarakan atas dukungan penelitian DIPA 2020 (Grant Number 015/UN51.9/CONTRACT-LT/2019) dan anggota Laboratorium Kimia Bahan Alam, Fakultas pertanian, Universitas Borneo Tarakan, Kalimantan Utara.

\section{DAFTAR PUSTAKA}

Ahmad, T., Ruky, S dan Palmi, P. 2002. Buku Pelajaran Teknologi Farmasi Edisi ke-5. UGM Press. Yogyakarta.

Bandaranayake WM. 2002. Bioaktivities, Bioaktive Compounds of Chemical Constituent and Mangrove Plants. Wetlands Ecology and Management Journal 10:421-452.

Chan EWC, Lim YY, Wong LF. Antioxidant and Tyrosine Inhibition Properties of Leaves and Rhizomes of Ginger Species. Food Chemistry. 109(3): 447-483.

Dewi MK, Ratnasari E, Trimulyono G. 2014. Aktivitas Antibakteri Ekstrak Daun Majapahit (Crescentia cujete) Terhadap Pertumbuhan Bakteri Ralstonia solanacearum Penyebab Penyakit Layu. Universitas Negeri Surabaya. Surabaya. 3(1): 51-57.

Egra S., Kusuma IW., Arung ET., Kuspradini H. 2019. The potential of white-oyster mushroom (Pleurotus ostreatus) as antimicrobial and natural antioxidant. Biofarmasi J Nat Pro Biochem. Vol 16 (1): $17-23$

Irsyad Muchammad. 2013. Standardisasi Ekstrak Etanol Tanaman Katumpangan Air (Peperomia pellucida L. Kunth). UIN Syarif Hidayatullah. Jakarta.

Kristian, J., Zain, S., Nurjannah, S. 2016. Pengaruh Lama Ekstraksi Terhadap Rendemen dan Mutu Minyak Bunga Melati Putih Menggunakan Metode Ekstraksi Pelarut Menguap. Fakultas Teknologi Industri Pertanian. Universitas Padjajaran. Bandung.

Kusumadewi, T., Khotimah, S., Yanti, A, H. 2015. Ekstrak Metanol Buah Sonneratia alba J.E.Sm sebagai Penghambat Pertumbuhan Helminthosporium sp. yang diisolasi dari Daun Jagung. Jurnal Protobiont, 3:2 ,149154.
Lamothe RG. 2009. Plant Antimicrobial Agents and Their Effects on Plant and Human Pathogents. Int. J. Mol. Sci. 10: 3400-3419.

Mulyani Y., Bachtiar eri., M, Untung. 2013. Peranan Senyawa Metabolit Sekunder Tumbuhan Mangrove Terhadap Infeksi Bakteri Aeromonas hydrophila Pada Ikan Mas (Cyprinus carpio L.). Universitas Padjajaran. Bandung.

Noor, Y. R. 2006. Panduan Pengenalan Mangrove di Indonesia. Wetland International Indonesia ProGramme.Bogor.

Nuria MC, Faizaitun A, Sumantri. 2009. Uji Aktivitas Antibakteri Ekstrak Etanol Daun Jarak Pagar (Jatropa curcas L) Terhadap Bakteri Staphylococcus aureus ATCC 25923, Escherichia coli ATCC 25922, dan Salmonella typhi ATCC 1408. Mediagro. 5(2): 26-37.

Olson, Kent, Edior. 2004. Poisoning and Drug Overdose Fourth Edition. California Poison Control System. California.

Ogata, M., M. Hoshi, S. Mangala and T. Endo. 2000. Antioxidant activity of eugenol and related monomeric and dimeric compounds. Chem. Pharm. Bull. 48(10) : 1467-1469.

Pelczar MJ, Chan ECS. 1986. Dasar-Dasar Mikrobiologi . Universitas Indonesia Press. Jakarta.

Purnobasuki H. 2004. Potensi mangrove sebagai tumbuhan obat. Jurnal Biota 9(2): 125-126.

Putri RR, Rafitah H \& Indrati K. 2016. Uji Aktivitas Antibakteri dan Uji Fitokimia Ekstrak Daun Mangrove Sonneratia alba. Universitas Mulawarman. 2(1): 43-50.

Rizki, A.A. 2018. Pengaruh Suhu dan Lama Pengeringan Kopra Terhadap Rendemen Minyak. Jurusan Teknik Pertanian. Fakultas Pertanian. Universitas Lampung. Lampung.

Rizkinita Putri, R., Hasanah, R., Kusimaningrum, I. 2016. Uji Aktivitas Antibakteri dan Uji Fitokimia Ekstrak Daun Mangrove Sonneratia alba. J. Aquawarman. Universitas Mulawarman. Samarinda.

Sjahid I.R. 2008. Isolasi dan Identifikasi Flavonoid dari Daun Dewandaru (Eugenia uniflora L). [Skripsi]. Universitas Surakarta.

Siregar A.F, Sabdono A, dan Pringgenies D. 2012. Potensi Antibakteri Ekstrak Rumput Laut Terhadap Bakteri Penyakit Kulit Pseudomonas aeruginosa, Staphylococcus epidermidis, dan Micrococcus leteus. Journal of Marine research. 1(2): 152-160. 
Siswandono W. 2000. Kimia Medisinal Ed ke-2. Airlangga University Press. Surabaya.

Sudarmadji, S.B. 2009. Analisis Mikrobiologi Pangan. Raja Gerindo Persada. Jakarta.

Sudira IW, Merdana IM, Wibawa IP. 2011. Uji Daya Hambat Ekstrak Daun Kedondong (Lannea grandis Engl) Terhadap Pertumbuhan Bakteri Erwinia carotovora. Buletin Veteriner Udayana.

Tapia M.S, Alzamora S.M, and Chirife J. 2007. Effects of water activity (aw) on microbial stability: As a Hurdle in Food Preservation. In: Water Activity in Foods: Fundamentals and Aplications. Barbosa-Canovas, G.V, Fontana Jr, A.J, Schmidt S.J, Labuza, TP (ed). Blackwell Publising. Lowa. USA.

Trianto, A. Wibowo E. Suryono, Sapta R. 2004. Ekstrak daun mangrove Aegiceras corbiculatum sebagai antibakteri Vibrio harveyi dan vibrio parahaemolyticus. Jurnal Ilmu kelautan. 9(4):186-189.

Wijaya Heri, Novitasari, Jubaidah S. 2018. Perbandingan Metode Ekstraksi Terhadap Rendemen Ekstrak Daun Rambai Laut (Sonneratia caseolaris L. Engl). Akademik Farmasi Samarinda. Samarinda.

Yanti, Kuspradini H., Putri AS. Egra S. 2019. Short Communication: In vitro antibacterial activity of essential oils from twelve aromatic plants from East Kalimantan, Indonesia. BIODIVERSITAS. Vol. 20 (7): 2039-2042. 